\title{
Profile of the newly graduated physicians in southern Brazil and their professional insertion
}

\section{Perfil do médico recém-formado no sul do Brasil e sua inserção profissional}

\author{
Kátia Sheylla Malta Purim"; luiza de Martino Cruvinel Borges²; Ana Carolina Possebom².
}

\begin{abstract}
A B S TR A C T
Knowledge of the profile and professional integration of new graduates enables adjustments in medical education. This study evaluated 107 graduates from a private institution in the Brazilian South region, using a self-administered electronic questionnaire. There were similar participation of young physicians of both genders and higher male concentration in general surgery. Graduates are inserted in the public and private labor market. Most do extra shifts in emergency services and trauma surgery, where there is greater need for clinical and surgical skills. These findings suggest that adequate surgical training during graduation is critical to employability.
\end{abstract}

Keywords: Medical Education, Human Resources for Health, Internship and Residency, Professional Practice, General Surgery.

\section{INTRODUCTION}

T he process of formation of human resources in health and its absorption in the labor market is complex, multifactorial and dynamici-6. Several medical schools are being opened, but little is known about the practice areas of their graduates, employment and continuing education for meeting the growing population demands in the country, especially in the emergency department and trauma surgery ${ }^{3,6,7}$.

The investigation of the trajectory of medical alumni can provide subsidies to adjust and improve teaching and welfare aspects of medical practice to different contexts and realities ${ }^{1,4,8,9}$.

In 2002, a private medical school started its activities in Southern Brazil, in an annual, full-time system, the first class graduating in January 2008. This course has a teaching hospital and various learning scenarios that combine techno-scientific advances incorporated into teaching ${ }^{7,10,11}$. However, it is still not precisely known the areas chosen for professional performance, continuing studies and regional coverage in health achieved. This study aimed to know the socioprofessional profile of these newly trained doctors, seeking input on the contribution of education in surgical insertion in the labor market.

\section{METHODS}

WE conducted a descriptive, transversal survey through a structured, self-administered, electronic questionnaire, whose content was validated by two professors of medicine and one statistician. The project was previously approved by the Ethics in Research Committee (protocol 742,871) and followed Resolution 466/2012 of the National Health Council, preserving confidentiality and anonymity. The pilot test to check the clarity, coherence and consistency of the questions was conducted with five former students excluded from the sample after adjustment of the questionnaire to avoid response bias.

To calculate the sample size, we considered a significance level of $5 \%, 90 \%$ power, and $50 \%$ chance of each former student to participate in the study. Taking into account the 319 doctors trained in the institution during the period between 2007 and 2013, we came to idealized sample of 147 individuals.

1 - Department of Dermatology and Ambulatory Surgery, Positivo University Medical School, Curitiba, PR, Brazil. 2 - Positivo University Medical School, Curitiba, PR, Brazil. 
For data collection, we used a structured questionnaire containing 25 closed questions, typed in Google Docs through free registration of one of the researchers, not allowing the identification of the respondents.

We assessed sociodemographic aspects such as gender, age, marital status; training received during undergraduate studies and initiatives for conducting courses, specializations and/or residences; labor market integration aspects, such as a number of hours worked, sources of income, places and areas; and the search for more specific technical improvement. Along with the questionnaire, we used the free and informed consent form (ICF) and a text explaining the study and its importance.

For the purpose of this study, medical activity, although comprehensive and focused on the needs of individuals and communities, was grouped in the main focuses of health services and actions, such as: primary care (Basic Health Unit, Family Health Unit, Private Practice and general outpatient clinics) and secondary/tertiary care (hospital, emergency room, emergency care and specialty outpatient clinic) and compared as to the gender of the newly formed.

We sent email questionnaires to all 319 graduates in August 2014, with a maximum period of thirty days to response return. In this first stage, we obtained 63 responses. Hence, there was a second round of electronic collection a month later using the same questionnaire and time, with published notes on the research by a group of former classmates, course coordination, professors and in social networking sites like Facebook and Twitter, resulting in 44 more questionnaires.

The data were stored in an Excel spreadsheet and treated using descriptive analyses performed using the Statistical Package for Social Sciences $13.0 \circledR$.

\section{RESULTS}

The sample totaled 107 physicians (response rate $33.5 \%$ ), which accounted for a third of medical graduates of this institution. There was a similar proportion of voluntary male participants $53(49.5 \%)$ and women 54 (50.5\%). The average age of men was 28.5 years, with a standard deviation of 2.8 years (range 23-39) and women displayed mean age of 27.6 years, with a standard deviation of 3.6 (range 23-43), with no statistical difference between genders. All graduates who answered the questionnaire were native Brazilians, 68 (63.5\%) being single, $27(25.2 \%)$ married and $12(11.2 \%)$ in a stable relationship.

In relation to geographical origin, 71 (66.4\%) have been living in the city where the course is offered, while $36(33.6 \%)$ came from other cities. Of the total respondents, 26 (24.3\%) graduates came from the Paraná state, five $(4.7 \%)$ from the State of Santa Catarina and one from each of the following states: São Paulo, Alagoas, Mato Grosso, Rio Grande do Sul and Minas Gerais. After graduation, 61 (57\%) remained in the same capital where they graduated, the others having moved to other locations.

Of the 107 respondents, $75(70.1 \%)$ chose to attend medical residency, 32 (29.9\%) had completed the service basic training program and $43(40.2 \%)$ were still attending the residence in preferably surgical areas.

When comparing the vocational post-graduation programs (residency, specialization) between genders, we identified a male preference for the areas of General Surgery (31\%), Internal Medicine (11\%), Radiology $(11 \%)$, Anesthesiology (8\%), Family Medicine (8\%), Cardiology (6\%), Orthopedics (6\%), Otolaryngology (6\%) and Gynecology-Obstetrics (6\%). Women preferred the fields of Gynecology-Obstetrics (23\%), Internal Medicine $(21 \%)$, Pediatrics (15\%), General Surgery (8\%) and Dermatology (5\%) (Figure 1).

At the time of the survey, the graduates had been carrying out the surgical career development plan in Ophthalmology, Neurosurgery and Plastic Surgery, seeking greater competence to highly complex activities.

The main source of income of graduates came from the practice of medicine $(92.5 \%)$, including income derived from the post-graduate program scholarship. About 74 (85\%) graduates had two or more jobs as doctors and of these 35 (40.2\%) had three or more professional ties.

Of the total sample, 19 (22\%) acted as standalone, 69 (79\%) in the public service and 58 (67\%) in the 
private, whereas, however, there are professionals working in more than one sector. The health coverage reached various locations and communities, with the highest concentration of women in secondary/tertiary sector (Figure 2).

When asked about the time directed to work as a doctor, we found professionals who worked up to 40 hours (56.3\%), less than 20 hours (16.1\%) and more than 61 hours (14.9\%) weekly. Among the 38 (35.5\%) who acted as liberal professionals in an office, half (50\%) had their own office and the other half (50\%) worked in group practices. About 55 (51\%) worked on medical shifts, with extra activities in emergency services and/or trauma surgery, and 18 (20.7\%) took leading/coordination positions.

When analyzing investments in updating, we observed participation in courses and conferences, as well as signing of indexed medical journals by 34 (31.8\%) participants, while $3.7 \%$ of them signed more than two journals. Regarding academic post-graduation, one graduate was attending PhD in Surgery.

As for the degree of satisfaction with career choice, 75 (90\%) were satisfied or very satisfied, while 8 $(10 \%)$ were dissatisfied. There was no record of profession withdrawal in the evaluated period.

\section{DISCUSSION}

Research on the socio-professional profile of newly graduated doctors through postal surveys have varying adherence percentages ${ }^{2,12,13}$. In this study, the active search for digital media resulted in the participation of 107 medical graduates from Curitiba-PR.

The obtained response rate (33.5\%) was higher than that achieved with graduates from Santo André-SP $(23.4 \%)^{2}$, Londrina -PR $(29.7 \%)^{12}$, similar to Canoas-RS $(32.1 \%)^{1}$, and lower than Botucatu $(45 \%)^{13}$. These differences can be attributed to methodological issues (use of printed media, electronic media, and telephone), as well as operational (outdated addresses) and individual ones (lack of awareness of the importance of the study and forgetting to respond and/or send the response). The criteria standardization for systematic evaluation of grad-

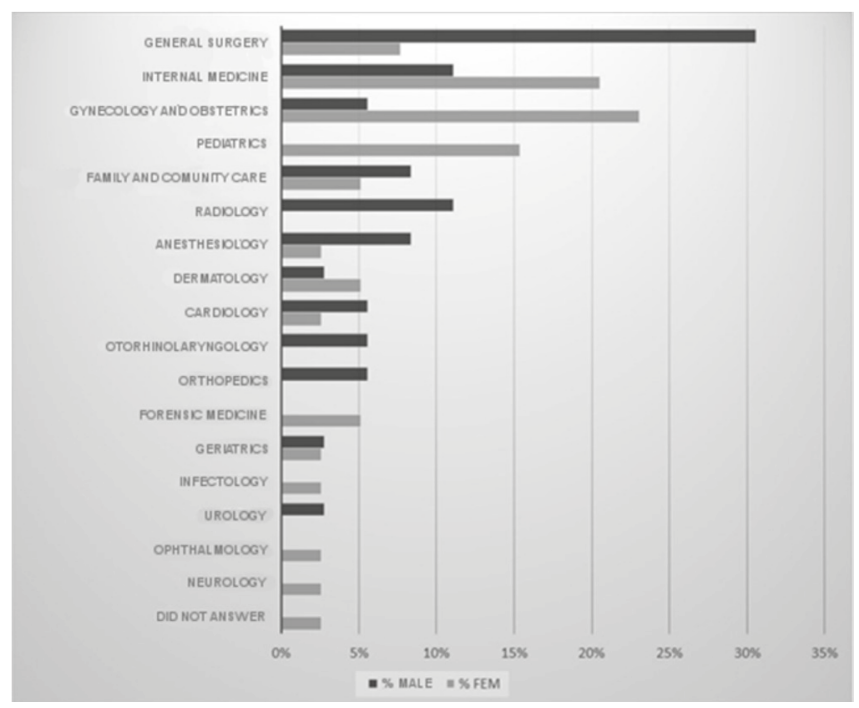

Figure 1. Medical Residency Area according to graduates' gender $(n=75)$.

uates, as well as of faculty and infrastructure of the institutions, is important to monitor and improve professional training ${ }^{14}$

As for the sociodemographic aspects, research shows that, since 2009, more female doctors enter the market than male ones ${ }^{1,4,15}$. In the present sample there was a homogeneous distribution by gender among the respondents. However, the prevalence of young single adults was similar to the national scenario ${ }^{2.4}$.

The full-time graduation structure complemented by extracurricular activities, both mandatory and voluntary, delays entry into the labor market and the construction of the nuclear family ${ }^{13,15}$. On the other hand, the absence of labor obligations before or during university attendance increases the importance of teaching and the effectiveness of learning to overcome the absence of such experience, to achieve success in various selection processes, and to competently respond to professional scientific technical requirements, to the social dimensions incorporated into the health-disease process and to the administrative and financial self-management $3,5,16,17$.

Research shows that younger doctors prefer to stay in the big cities where they completed their courses, remaining in the states of origin ${ }^{4,12}$. In agreement with the literature, there was little mobility between graduates coming from Paraná, seat of this medical school.

In this sample, the highest percentage of graduates staying in the capital can be attributed to the exis- 


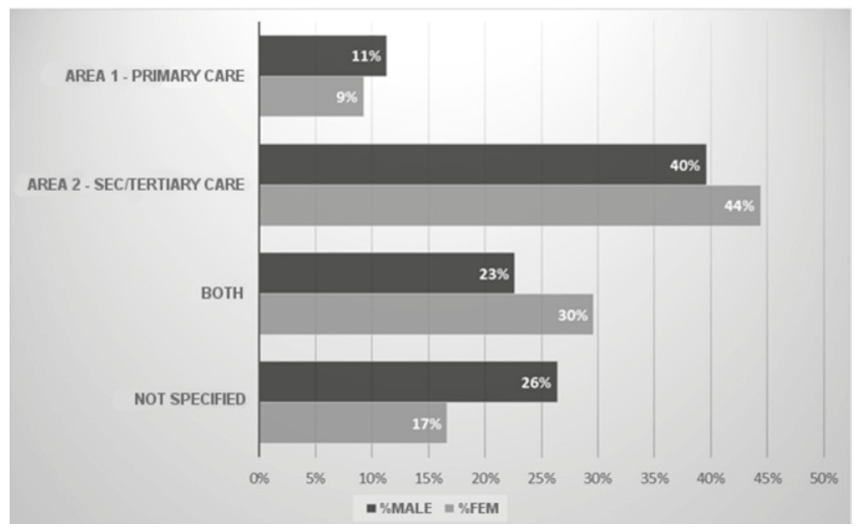

Figure 2. Health Coverages according to graduates' gender $(n=107)$.

tence of various medical and hospital complexes, accredited residency programs, alternative work, leisure and urban mobility, corroborating other authors ${ }^{1,2,12,18}$.

Recent studies show that current generations demonstrate changes in rewards structure and interest in the medical profession, valuing more quality of life and financial resources $5,15,16,19$.

Extra shifts as autonomous in emergency departments and trauma surgery, especially in private hospitals, are an often choice of financial support at this early stage $^{3,4}$. Therefore, it is essential the clinical and surgical training that includes technical proficiency of medical routine procedures to provide adequate assistance ${ }^{3,6-8,17}$. The findings of this study indicate that the training received has enabled good health coverage and employability alternatives.

The residency program is an important means of professional training for the physician ${ }^{9,16-18}$. Unlike the findings of Feitosa-Filho et al., in $2012^{19}$, most graduates of this sample have chosen to attend residency and the preference for general surgery may indicate motivating teaching-learning opportunities in medical school7,10,11,16. On the other hand, the reduced presence of women in this surgical specialty probably reflects the difficulties to reconcile the professional women's interests with the personal ones, including marriage and motherhood ${ }^{15}$.

Research shows that the doctor performs multiple simultaneous occupational tasks, mostly of assistance nature ${ }^{4}$. Our findings demonstrate professional practice in primary, secondary and tertiary care, the public sector being the main employer of the newly formed, reflecting features of the profile observed by the survey conducted by the Federal Council of Medicine and by regional studies $3,4,18$.

The rapid and increasing knowledge, practices and technologies in the medical field require continuing education ${ }^{6,8}$. In general, students and professionals attend courses, conferences and scientific technical events, on-site or remotely, as well reading of books and scientific articles $6,10,16$. In this investigation, we found that most graduates continued to invest in education and professional self-development. The high frequency of satisfaction detected with the professional choice can point out that the expectation of these graduates is good in relation to their future.

We should highlight the limitations of this work. There was no stratification of graduates by year of graduation. In addition, this exploratory study refers to early-career physicians (maximum of five years and a minimum of one year of professional practice) who have submitted to the Inter-institutional Medical Progress Test during graduation ${ }^{18}$. Reviews of users, managers and supervisors on the practice of these doctors, as well as statistical analysis of possible combinations of variables such as economic status, satisfaction, income and working conditions, could reveal other angles and perspectives.

On the other hand, it lacked specification of aspects of medical skills that helped or not the graduate to feel able to act in emergency services. In this sector, there is greater need for precise physical examination, quick decisions, application of techniques and effective conducts to reduce errors, delay or loss of diagnoses that can impact quality of care and patient survival ${ }^{6-8,20}$.

The findings of this study suggest that the incorporated training helped to form physicians with general skills to enter the labor market, meet the health needs of the population and maintain the commitment to professional development. Thus, one can infer that the current performance of these graduates was consistent with the medical profile we expected to form.

Nonetheless, the way to practice and teach medicine must be constantly reflected upon, improved and adapted to the demands of professional training, either undergraduate or graduate, and in continuing edu- 
cation aimed at current and future quality of medical care to the population.

\section{CONCLUSIONS}

The sociodemographic profile showed young and single graduates, with similar genders' ratio, who have continued training through the residency program, with male predominance in general surgery. The newly trained physicians are integrated into the public and private labor market and act as physicians in emergency services. Regardless of the chosen specialty, skills and basic surgical skills are important for professional practice.

\section{RE S U M O}

O conhecimento do perfil e inserção profissional dos recém-formados possibilita ajustes na educação médica. Este estudo avaliou 107 egressos de instituição privada no sul do país, utilizando questionário eletrônico autoaplicável. Houve participação similar de jovens de ambos os sexos e maior concentração masculina na área de cirurgia geral. Os egressos estão inseridos no mercado de trabalho público e privado. A maioria faz plantões extras em serviços de emergência e cirurgia do trauma, onde há maior necessidade de habilidades clinicas e cirúrgica. Esses achados apontam que a formação cirúrgica adequada durante a graduação é fundamental para a empregabilidade.

Descritores: Educação Médica. Recursos Humanos em Saúde. Internato e Residência. Exercício Profissional. Cirurgia Geral.

\section{REFERENCES}

1. Caovilla F, Leitzke L, Menezes HS, Martinez PL. Perfil do médico egresso do Curso de Medicina da Universidade Luterana do Brasil (Ulbra). Rev AMRIGS. 2008;52(2):103-9.

2. Castellanos MEP, Silveira AFMH, Martins LC, Nascimento VB, Silva CS, Bortollotte FHB, et al. Perfil dos egressos da Faculdade de Medicina do ABC: o que eles pensam sobre atenção primária em saúde? Arq Bras Ciên Saúde. 2009;34(2):71-9.

3. Campos MCG, Senger MH. O trabalho do médico recém-formado em serviços de urgência. Rev Bras Clin Med São Paulo. 2013;11(4):1-5.

4. Scheffe M, coordenador. Demografia médica no Brasil: cenários e indicadores de distribuição. São Paulo: CFM; CREMESP; 2013.

5. Corsi PR, Fernandes EL, Intelizano PM, Montagnini CCB, Baracat FI, Ribeiro MCSA. Fatores que influenciam o aluno na escolha da especialidade médica. Rev Bras Educ Med. 2014;38(2):213-20.

6. Parreira JG, Campos T, Perlingeiro JAG, Soldá SC, Assef JC, Gonçalves AC, et al. Implantação de registro de trauma como ferramenta para melhorar a qualidade do atendimento a traumatizados: os primeiros 12 meses. Rev Col Bras Cir. 2015;42(4):265-72.

7. Purim KSM, Skinovsky J, Fernandes JW. Habilidades básicas para cirurgias ambulatoriais na graduação médica. Rev Col Bras Cir. 2015;42(5):341-4.

8. Ministério da Educação. Conselho Nacional de Educação. Câmara de Educação Superior. Diretrizes Curriculares Nacionais do Curso de Graduação em Medicina Resolução CNE/CES 3/2014. Diário Oficial da União, Brasília, 23 de junho de 2014 - Seção 1. p. 8-11.

9. Nogueira Ml. As mudanças na educação médica brasileira em perspectiva: reflexões sobre a emergência de um novo estilo de pensamento. Rev Bras Educ Med. 2009; 33(2):262-70.

10. Purim KSM, Skinovsky J, Fernandes JW. Uso de painel de artigos cientificos no ensino da cirurgia ambulatorial. Rev Col Bras Cir. 2013;40(6):490-3.

11. Purim KSM. Oficina de cirurgia cutânea. Rev Col Bras Cir. 2010;37(4):303-5.

12. Sakai MH, Cordoni Jr L. Os egressos da medicina da Universidade Estadual de Londrina: sua formação e prática médica. Rev Espac Saúde. 2004;6(1):34-47.

13. Torres AR, Ruiz T, Müller SS, Lima MCP. Qualidade de vida e saúde física e mental de médicos: uma autoavaliação por egressos da Faculdade de Medicina de Botucatu - UNESP. Rev Bras Epidemiol. 2011;14(2):264-75.

14. Ribas Filho JM, Paiva EV. Porque e como avaliar o egresso do curso de medicina [editorial]? $A B C D$, arq bras cir dig 2013;26(1):1. 
15. Franco T, Santos EG. Mulheres e cirurgiãs. Rev Col Bras Cir. 2010;37(1):72-7.

16. Watte G, Manfroi WC, Machado CLB, Mantuan BC, Moreira ALS, Oliveira FM, et al. Componentes determinantes na escolha da especialização em novos profissionais médicos. Rev Bras Educ Med. 2015;39(2):193-5.

17. Macedo DH, Batista NA. O mundo do trabalho durante a graduação médica: a visão dos recém-egressos. Rev Bras Educ Med. 2011;35(1):44-51.

18. Sakai MH, Ferreira Filho OF, Almeida MJ, Mashima DA, Marchese MC. Teste de progresso e avaliação do curso: dez anos de experiência da medicina da Universidade Estadual de Londrina. Rev Bras Educ Med. 2008;32(2):254-63.

19. Feitosa-Filho GS, Loureiro CM, Almeida NR, Mascarenhas VN, Camurugy TC, Magalhães LB. Razões ale- gadas por médicos recém-formados em Salvador/BA em 2010 para não prestarem o concurso de residência médica. Rev Bras Clin Med. 2012;10(2):91-4.

20. Verghese A, Charlton B, Kassirer JP, Ramsey M, loannidis JP. Inadequacies of physical examination as a cause of medical errors and adverse events: a collection of vignettes. Am J Med. 2015;128(12):1322-4. Epub 2015 Jul 2.

Received in: 11/03/2016

Accepted for publication: 21/06/2016

Conflict of interest: none.

Source of funding: none.

\section{Mailing address:}

Kátia Sheylla Malta Purim

E-mail: kspurim@gmail.com 